\title{
Galium parisiense var. leiocarpum Tausch, New for Oklahoma
}

\author{
Lawrence K. Magrath \\ Curator, USAO (OCLA) Herbarium \\ Chickasha, Oklahoma73018-5358
}

While doing some routine plant collecting in Chickasha in June of 1999 I found a Galium with which I was not familiar. However, when I tried to key it out in Smith (1994) it immediately keyed to Galium parisiense L. var. leiocarpum Tausch. It also keyed out in Fernald (1950), Britton (1907), and Munz and Keck (1963) and Hickman (1993). This species is originally from Europe.

OKLAHOMA: GRADY COUNTY: Chickasha, Walmart Plaza on Ponderosa Drive; T6N, R7W, SW 1/4 Sec 3; open disturbed grassy area on west side of street, red clay and some sand; elevation ca $1100 \mathrm{ft}$; scattered to locally abundant in ca 5 acre area; flowers greenish-white, some with red-brown corolla lobes; 9 June 1999; L.K. Magrath 20590 (OCLA). Additional collections at same site: 25 June 1999; L.K. Magrath, Pete Taylor, et al 20693 (OCLA). 27 May 2001; L.K. Magrath 21449 (OCLA). 24 June 2001; L.K. Magrath 21452 (OCLA). Plants dead but with some seeds persisting.

OKLAHOMA: OKLAHOMA

COUNTY: Oklahoma City, Will Rogers Park and Garden Center at NW $36{ }^{\text {th }}$ Street and I-240; grassy area near edge of wooded area southeast of Rose Garden; scattered; most plants already dead, but with some seeds persisting; 16 June 2001; L.K. Magrath 21451 (OCLA)

Also found at the same site: Galium pedemontanum (Bell.) All. OKLAHOMA: GRADY COUNTY: Chickasha, Walmart Plaza on Ponderosa Drive; T6N, R7W, SW 1/4 Sec 3; open disturbed grassy area on west side of street, red clay and some sand; elevation ca $1100 \mathrm{ft}$; scattered to locally abundant in ca 5 acre area; flowers yellow to greenish-yellow; 25 April 2001; L.K. Magrath, Stephen Garvin, Val Maseykin et al. 21344 (OCLA); another collection at same site: 27 May 2001; L. K. Magrath 21448 (OCLA).

Significance: Galium parisiense L. var.

leiocarpum Tausch represents an extension west from north central Arkansas (Baxter, Fulton, Newton \& Pope Counties). This is a rather significant jump to the west from Ozarkian woodlands habit to a relatively open mid-grass prairie habitat. The Galium pedemontanum (Bell.) All. is an extension northward and westward from southern and eastern Oklahoma (Taylor \& Taylor 1994). I would guess that both species arrived in Chickasha via freight being delivered to the WalMart Shopping Center. The Oklahoma City location is near an area with numerous visitors, and next to an interstate highway, so there are several possibilities that might account for its presence at this location. It may be worth checking similar locations in other cities in Oklahoma for these species and other possible introductions.

\section{REFERENCES:}

Britton, N. L. 1907. Manual of the Flora of the Northern States and Canada. 2nd ed. Henry Holt \& Co. NY.

Fernald, M. L. 1950. Gray's Manual of Botany. $8^{\text {th }}$ ed. American Book Co. NY.

Gleason, H. A. and A. Cronquist. 1963. Manual of Vascular Plants of Northeastern United States and Adjacent Canada. D. Van Nostrand Co., Inc. Princeton, N.J.

Hickman, J. C. ed. 1996. The Jepson Manual: Higher Plants of California. Univ. of California Press. Berkeley, CA

Munz, P. A. \& D. D. Keck. 1963. A California Flora. Univ. of California Press. Berkeley, CA.

Smith, E. B. 1978. An Atlas and Annotated List of the Vascular Plants of Arkansas. Dept. of Botany \& Bacteriology, Univ. of Arkansas at Fayetteville; Fayetteville, AR.

Smith, E. B. 1994. Keys to the Flora of Arkansas. Univ. Arkansas Press; Fayetteville, AR.

Taylor, R. J. \& C. E. S. Taylor. 1994. An Annotated List of the Ferns, Fern Allies, Gymnosperms and Flowering Plants of Oklahoma. Biology Dept. Herbarium, Southeastern Oklahoma State Univ.; Durant, OK 